既報 ${ }^{1}$. 2)において、数種の土袞処理型除草郕が水稲の茎葉部及び根部に及ほす形態 的影響について、稚苗と乳苗との比較及び直播水稲の検討を行ってきた。本報ではそ れらの結果に基づいて、水稲の葉と根部において葉位あるいは要素別に見た場合の形 態的影響の発現状況及び相互関係について考察を行った。以下の考察は、既報におけ るベンスルフロンメチル・ジメビベレート処理による植付（播種）深度 $1 \mathrm{~cm}$ の場合 の形態的影響を主体とし、他の除草剤による影響も加味して行ったものである。

1. 形態的影留の模式図

処理時の水稲の生長段階を要素の考え方 ${ }^{3}$ をもとに模式図化したものを第 1 図上段 に示した。稚苗は第 5 葉展開期（不完全葉を第 1 葉とする、以下同様）、乳苗は第 4 葉展開期、直播水稲は第 2 葉抽出期に除草剂処理を行った。その後生長した水稲の葉 位あるいは要素根における形態的影響の有無及びその程度を第 1 図下段に示した。

(1)稚苗：除草剤処理時に抽出直前であった第 6 葉の葉鞘から伸長抑制が現れ、第 7 葉が最も強い影響を受けた。根は第 4 要素根の一部に伸長抑制が現れ、第 5 要素根が 最も強い影響を受けた。

(2)乳苗：処理時に抽出直前であった第 5 葉の葉鞘から伸長抑制が現れ、第 $6 \sim 7$ 葉 が強い影響を受けた。根は第 3 要素根の一部に伸長抑制が現れ、第 4 要素根が最も強 い影響を受けた。

(3)直播水稲: 処理時に出葉中であった第 2 葉及び次の第 3 葉にはほとんど影響がな く、第 $4 、 5$ 葉に強い伸長印制が現れた。根は第 1 要素根の一部が伸長抑制を受け、 第 3 要素根が最も強い影響を受けた。

\title{
2. 除草剂処理時の水稲の生育段階の違いと形態的影脊の発現との関係
}

第 $\mathrm{N}$ 葉の抽出と第 $(\mathrm{N}-3)$ 要素の出根が同調する ${ }^{31}$ と考えた場合の葉と根の生長の 対応関係に基づいた形態的影響の発現状況を第 2 四に示した。いずれの生長段階にお ける水稲においても、ほほ同時期に生長しつつある葉及び根が除草剤による影響を受 けることが認められた。また生育段階の早い時期に処理された水稲では、より低い葉 位あるいは要素根に影響が現れていた。このことから、除草剤か若跉水稲により大き な薬害症状をもたらすのは、生理的に感受性が高いことに加え、既展開葉あるいは既 伸長根の少ないことが関わっているものと考えられる。さらに稚苗及び乳苗では、根 における影響の発現か対応関係にある葉よりも若干遅かったか、これは第 $\mathrm{N}$ 葉の抽出 時には第 $(\mathrm{N}-3)$ 要素根は約 $2 \mathrm{~cm}$ 伸長しているという関係 ${ }^{3)}$ があり、根の伸長が る程度進んだ根の生長点は処理層下に位置するためにその影響が次の要素の根に現れ たものと推察される。

$<$ 引用文献 $>$

1)藤田究・井之川育篤・吉田一史・石井清文 1991. 雑草研究 37別, 28-29.

2 ) 藤田究 1999 . 雑草研究 44(1),43-50.

3)川田信一郎 · 山崎耕宇 ·石原邦 ·芝山秀次郎 - 頼光隆 1963. 日作紀 32(2), 163-180.

Fujita, K. : Discussion about Morphological Effects of Soil Application of Herbicides on Rice Seedlings Applied at Different Growth Stages. 


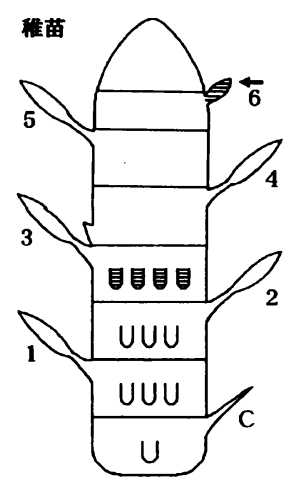

马

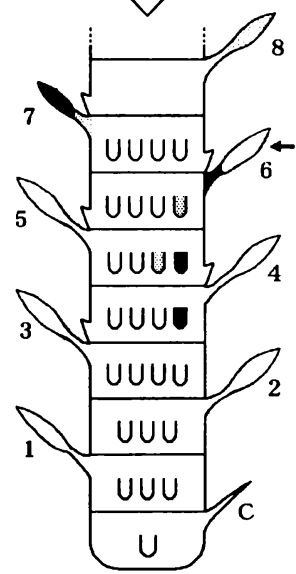

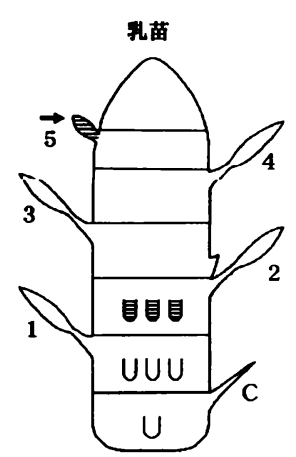

Љ

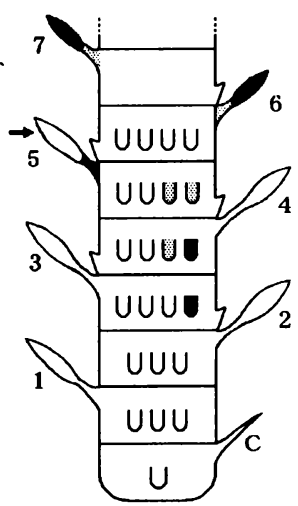

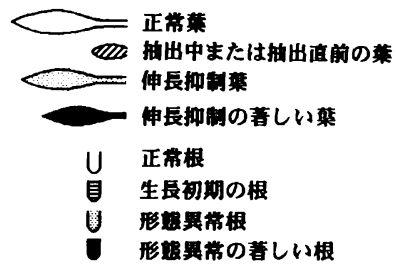

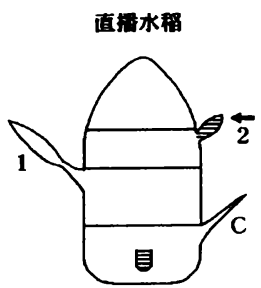

Љ

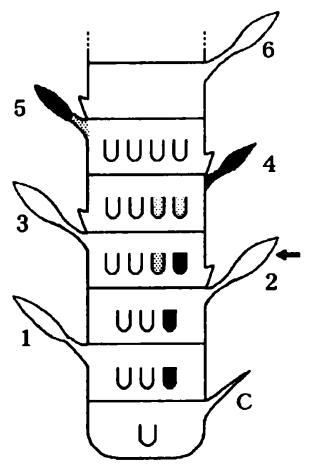

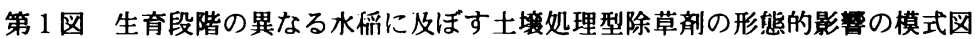
注1)川田 ${ }^{3)}$ の要素の考え方に基づいて作図し、横線は節を、Cは艄菓の要素、数字は要素番号を示す。

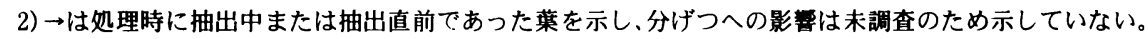

\begin{tabular}{|c|c|c|c|c|c|c|c|c|}
\hline \multirow{4}{*}{ 稚 苗 } & 菓位 & C, 1 & $2 \sim 4$ & 5 & 6 & 7 & 8 & 9 \\
\hline & 葉 & & & & & & 8 & \\
\hline & 要素 & $\mathrm{S}$ & 1 & 2 & 3 & 4 & 5 & 6 \\
\hline & 根 & & & & & & & \\
\hline
\end{tabular}

\begin{tabular}{|c|c|c|c|c|c|c|c|c|c|}
\hline \multirow{3}{*}{ 乳 苗 } & 葉位 & $\mathrm{C}, 1$ & $2 \sim 4$ & 5 & 6 & 7 & 8 & 9 \\
\cline { 2 - 10 } & 葉 & & & & & & & \\
\cline { 2 - 9 } & & 要素 & $\mathrm{S}$ & 1 & 2 & 3 & 4 & 5 & 6 \\
\hline
\end{tabular}

\begin{tabular}{|c|c|c|c|c|c|c|c|c|}
\hline \multirow{3}{*}{$\begin{array}{ll}\text { 直 } & \text { 播 } \\
\text { 水 } & \text { 馡 }\end{array}$} & 葉位 & C, 1 & $2 \sim 4$ & 5 & 6 & 7 & 8 & 9 \\
\hline & 葉 & & & & & & & \\
\hline & 要素 & $\mathrm{S}$ & 1 & 2 & 3 & 4 & 5 & 6 \\
\hline & 根 & & & & & 8 & & \\
\hline
\end{tabular}

第 2 図 生育段階の異なる水稲に及ぼす形態的影詈の葉と根の対応関係

注1)

: 影稫を強く受けた葉位または要素、

3. : 影椑を受けた葉位または要素

2)数字は要素番号を示し、Cは輎葉、Sは種子根を示す。

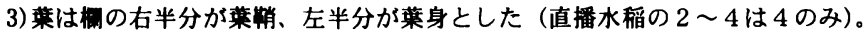

4)根は 1 要素内に 1 本でも強く影㫪を受けたものは要素全体が影笠を受けたものとした。 